\title{
Dorota Masłej, Modlitwa Pańska w polskim średniowieczu. Znad staropolskich rękopisów, Wydawnictwo „Rys”, Poznań 2016, ss. 141
}

O celu swojej pracy tak najzwięźlej i najbardziej rzeczowo pisze sama Autorka: „Niniejsza książka ma na celu zebranie i udostępnienie zachowanych polskojęzycznych wersji Ojcze nasz powstałych w średniowieczu (rozdział 3) oraz ich charakterystykę źródłoznawczą (rozdział 2 i 3 ) i językową (rozdział 4). [...] Ponieważ Modlitwa Pańska szybko stała się elementem życia społecznego, przedstawiono też, jak zmieniało się stanowisko polskiego Kościoła wobec odmawiania jej po polsku (rozdział 1). Ostatni rozdział jest natomiast istotnym kontekstem dla rozważań językowych, gdyż stanowi omówienie łacińskiego metajęzykowego komentarza dotyczącego thumaczenia modlitw na język polski (rozdział 5) i daje wyobrażenie o ówczesnej świadomości językowej” (s. 7).

Jak wiadomo historykom języka polskiego, próbę zbiorowego wydania i omówienia polskich przekazów Modlitwy Pańskiej pierwszy podjął Jerzy Samuel Bandtkie, a po nim Jan Bystroń (przy czym w tym wypadku nie chodzi o edycję, lecz jedynie o analizę, natomiast Bystroń nie ograniczył się do tekstu Ojcze nasz, lecz uwzględnił także Pozdrowienie Anielskie, Skład Apostolski i Dziesięcioro Przykazań). Obie próby nie odpowiadają jednak współczesnym standardom edytorskim, a przede wszystkim są dalece niekompletne (po prostu dzisiaj znamy nieporównanie więcej średniowiecznych przekazów Modlitwy Pańskiej w języku polskim).

W moim przekonaniu o wartości książki Doroty Masłej stanowią w największym stopniu następujące elementy i okoliczności:

A. Kompletność podstawy źródłowo-materiałowej, rozumiana jako uwzględnienie wszystkich dotychczas odnalezionych (w liczbie 23) odpisów Modlitwy Pańskiej (Autorka pominęła tylko drobne urywki Ojcze nasz zapisane 
w Modlitewniku Wacława). Z 23 znanych dziś przekazów Modlitwy Pańskiej nie wszystkie zachowały się fizycznie do naszych czasów, Autorka jednak uwzględniła również te, które znane są tylko z (różnej jakości) wydań, gdyż same rękopisy zaginęły lub zostały zniszczone. Wszystkie przekazy pochodzą z XV i początków XVI wieku, Autorka jednak przychyla się do opinii Tomasza Miki, Agnieszki Słobody i Wiesława Wydry, że nie zachowane i stąd w żaden sposób nie znane przekazy modlitw katechizmowych mogły powstawać już w XIII i XIV wieku, a burzliwe dzieje Polski spowodowały, że z piśmienniczego dorobku średniowiecza zachował się tylko znikomy ułamek (według Wydry mniej niż 5\%).

B. Rola Modlitwy Pańskiej w dziejach chrześcijaństwa, o której tak pisze Autorka: „Od zarania dziejów Modlitwa Pańska odgrywała szczególnie istotną rolę w Kościele. Ojcze nasz było tekstem żywym w wielu obszarach funkcjonowania Kościoła: istotnym w liturgii, w indywidualnej modlitwie wiernych. Pełniło funkcję wykładu podstawowych prawd wiary, wreszcie było też tekstem żywym teologicznie, stanowiąc przedmiot wielu komentarzy Ojców Kościoła. Było także pierwszą modlitwą, która służyła działalności misyjnej oraz nauczaniu katechetycznemu na poziomie elementarnym. [...] Pater noster w oczywisty sposób towarzyszył chrystianizacji kolejnych państw w średniowieczu, także słowiańskich. Na ziemiach polskich miała ona charakter długotrwałego, wielowiekowego procesu, zapoczątkowanego przyjęciem chrztu przez Mieszka I [...]” (s. 9-10).

C. Stosowna, adekwatna do przedmiotu książki metodologia - najogólniej mówiąc, metodologia filologii staropolskiej w jej najwyższym, zalecającym się godną podziwu akrybią, współczesnym standardzie.

D. Wszechstronność opracowania edytorskiego, na które składa się fotograficzna podobizna rękopisu (a same rękopisy zostały bardzo sumiennie opisane pod względem kodykologicznym na s. 30-44), na nowo przygotowana transliteracja i samodzielnie opracowana transkrypcja.

E. Wnikliwy i trafny komentarz językowy, dzięki któremu, jak słusznie zauważyła recenzentka wydawnicza, Monika Opalińska (cytuję z fragmentu recenzji pomieszczonego na czwartej stronie okładki): „Pozornie wąski temat, którego centrum stanowi średniowieczny polski przekład modlitwy Pater noster, jest w szczególności zgrabną syntezą i przyczynkiem do dziejów polskiej chrystianizacji. Drobiazgowa analiza naj- 
ważniejszej chrześcijańskiej modlitwy pozwala autorce nie tylko zrekonstruować proces kształtowania się polskiej formuły Ojcze nasz, ale również pokazać ewolucję języka i stylu religijnego w polskich tekstach modlitewnych".

F. Interpretacja arcyciekawego komentarza Jakuba z Piotrkowa. Komentarz ten, sformułowany po łacinie najprawdopodobniej ok. 1410 roku, odnosi się do tłumaczeń starszych, dziś nam nie znanych. Do niedawna był niemal nieobecny w obiegu naukowym, do którego został wprowadzony właśnie przez Dorotę Masłej, w dwu artykułach z 2015 roku. Jak trafnie zauważa Autorka: „Komentarz Jakuba z Piotrkowa pokazuje, że najdrobniejsze nawet różnice pomiędzy wersjami Ojcze nasz mogły być przedmiotem refleksji ówczesnych ludzi Kościoła w Polsce. Autor [...] przykłada wagę nie tylko do poprawności teologicznej: poszukuje adekwatności językowej, poświęca uwagę zagadnieniom gramatycznym, pokazując jednocześnie wysoką świadomość językową (zarówno łacińską, co oczywiste, jak i polską). Warto w tym miejscu podkreślić, że Jakub nie dąży za wszelką cenę do wierności łacinie [...], nie narzucając jednego poprawnego thumaczenia. Wypada więc w tym miejscu zauważyć, że Jakub z Piotrkowa, kanonik i egzaminator księży podejrzanych o herezję, nie dopuszczałby żadnej wariantywności polskiego tekstu Ojcze nasz, gdyby znał jakąś zatwierdzoną przez Kościół w Polsce rodzimą wersję modlitwy (a z racji pełnionej funkcji i ogromnej erudycji znałby ją na pewno). Trudno mieć wątpliwości, że za jego czasów proces standaryzacji dopiero się dokonywał, a kanonicznej postaci Modlitwy Pańskiej po polsku ani jeszcze nie zaproponowano, ani nie propagowano" (s. 121-128).

G. Wreszcie jako skutek wszystkich wyliczonych wyżej zalet interesujące i doniosłe wyniki naukowe. W moim przekonaniu na czoło wśród nich się wysuwa bardzo dla historii języka polskiego istotna korektura znanej tezy Zenona Klemensiewicza z 1961 roku, powtórzonej w 2011 roku przez Krzysztofa Maćkowiaka, o tym, że polskie teksty modlitw katechizmowych (a wśród nich Modlitwy Pańskiej) ze względu na ich ważność były dostarczane duchownym w postaci autoryzowanej przez zwierzchność kościelną i że mogły to być najwcześniejsze chronologicznie przejawy ogólnopolskiego języka literackiego w dziedzinie kościelnej. Tymczasem zarówno przytoczony wyżej wniosek z analizy komentarza Jakuba z Piotrkowa, jak i wnioski z analizy całego zestawu przekazów Modlitwy Pańskiej z XV i początków XVI wieku dowodzą, że kanoniczny tekst modlitw katechi- 
zmowych ukształtował się późno, a opinia Klemensiewicza, całkowicie intuicyjna (choć oparta na racjonalnym domyśle), jest bezzasadna.

Do walorów książki Doroty Masłej trzeba jeszcze dodać zalety stylu: Autorka, świetna stylistka, jest obdarzona nieczęsto spotykaną umiejętnością pisania w sposób naukowo ścisły i precyzyjny, a jednocześnie czytelniczo atrakcyjny. Najogólniej swoje wrażenia z lektury sformułowałbym tak: jeśli leciwy historyk języka polskiego w wyniku tej lektury nie tylko uporządkował sobie jakiś obszar dziejów polszczyzny pod względem źródłowo-materiałowym, lecz także dowiedział się czegoś całkiem nowego (zob. punkt G), to Autorka może to sobie poczytać za komplement.

Bogdan Walczak 